\title{
Distribution and abundance of early life stages of squid (Illex argentinus) in the south-west Atlantic
}

\author{
Norma E. Brunetti and Marcela L. Ivanovic
}

Brunetti, N. E., and Ivanovic, M. L. 1991. Distribution and abundance of early life stages of squid (Illex argentinus) in the south-west Atlantic. - ICES J. mar. Sci., 49: 175-183.

\begin{abstract}
A joint research cruise (Japan-Argentina-Uruguay) was carried out in the South-western Atlantic during August-September 1989 in order to study the winter-spawning and hatchery areas of Illex argentinus, and also the migration pattern of the juveniles towards the continental shelf. A few Rhynchoteuthion larvae were found in subtropical waters of the Brazil Current, next to the Brazil-Malvinas confluence, and in the frontal zone with shelf water, but never at temperatures below $14^{\circ} \mathrm{C}$. Large numbers of juveniles found in subantarctic waters $\left(6-10^{\circ} \mathrm{C}\right)$ on the shelf were probably migrating southward from their hatchery grounds following the zooplankton concentrations on which they were feeding.
\end{abstract}

Received 16 January 1991; accepted 17 September 1991

Norma E. Brunetti and Marcela L. Ivanovic: Instituto Nacional de Investigación y Desarrollo Pesquero C.C. 175, 7600 Mar del Plata, Argentina.

\section{Introduction}

In 1988 the Japanese government proposed to Argentina and Uruguay that a joint research cruise should be carried out in the South-western Atlantic, the aim being to study the winter-spawning and hatchery areas of Illex argentinus. The migration pattern of the juveniles towards the continental shelf would also be studied.

On the basis of data from earlier research cruises carried out by the Japanese RV "Shinkai Maru" during 1978/1979, Hatanaka et al. (1985) suggested that the species could spawn somewhere in the north of the area, in waters of the Brazil Current, in which the young, planktonic squid were then transported back to the south.

Leta (1987) described Rhynchoteuthion larvae (1.0$6.9 \mathrm{~mm}$ mantle length $=\mathrm{ML}$ ) of Illex argentinus from the continental shelf $\left(37-39^{\circ} 30^{\prime} \mathrm{S}\right)$, which were caught during the spring, and also from the slope between $35^{\circ} \mathrm{S}$ and $37^{\circ} \mathrm{S}$ during the winter.

The Soviet RV "Evrika" surveyed the oceanic region between $35^{\circ} \mathrm{S}$ and $50^{\circ} \mathrm{S}$ and as far as $35^{\circ} \mathrm{W}$ during AugustOctober 1988. During the Soviet-Argentinian research cruise, both larvae and juveniles of Illex argentinus were collected for the first time from that area. The larvae occurred at two stations at the southern edge of the Brazil Current $\left(36^{\circ} 30^{\prime} \mathrm{S}-49^{\circ} 10^{\prime} \mathrm{W}\right.$ and $\left.37^{\circ} 30^{\prime} \mathrm{S}-47^{\circ} 44^{\prime} \mathrm{W}\right)$. Juveniles were caught at 27 stations, mostly between $40^{\circ} \mathrm{S}$ and $50^{\circ} \mathrm{S}$, in the mixed zone from subantarctic and subtropical waters surrounding the warm meanders and eddies originating from the Brazil Current (Anon., 1989; Brunetti and Rossi, 1990; Parfeniuk et al., MS). Those juveniles ranged from 1.9 to $4.6 \mathrm{~cm} \mathrm{ML}$, and were 2-3 months old, according to statolith readings carried out later (Anon., 1989)

Brunetti (1988, 1990) described Rhynchoteuthion larvae of the summer-spawning subpopulation of Illex argentinus. This stock spends most of its biological cycle (including pre-adult forms, spawning and hatching) in shelf waters. Juveniles from this group are often caught on the outer shelf and continental slope during winter (Brunetti, 1981; Brunetti and Rossi, 1990).

Haimovici et al. (MS) found Rhynchoteuthion larvae and juveniles of Illex argentinus in Brazilian waters between $29^{\circ} \mathrm{S}$ and $35^{\circ} \mathrm{S}$ during spring and winter. The higher abundances were recorded during winter at the western boundary of the Brazil Current, in slope waters and subsurface subtropical waters.

As a result of the agreement of both Argentina and Uruguay with the Japanese proposal mentioned above, a research cruise (RV "Kaiyo Maru") was carried out during August and September 1989.

Although the cruise failed to detect egg masses, it is possible to report results on the distribution of larvae and juveniles and possible relationships with oceanographic features and conditions in winter.

\section{Materials and methods}

The cruise (27 August to 16 September) covered the waters of the Argentinian and Uruguayan shelf, and the continental slope and open sea between latitudes $35^{\circ} \mathrm{S}$ and $45^{\circ} \mathrm{S}$ and west of $50^{\circ} \mathrm{W}$. The survey comprised two cruises, the first leg of three transects $(A, B, C)$, the 


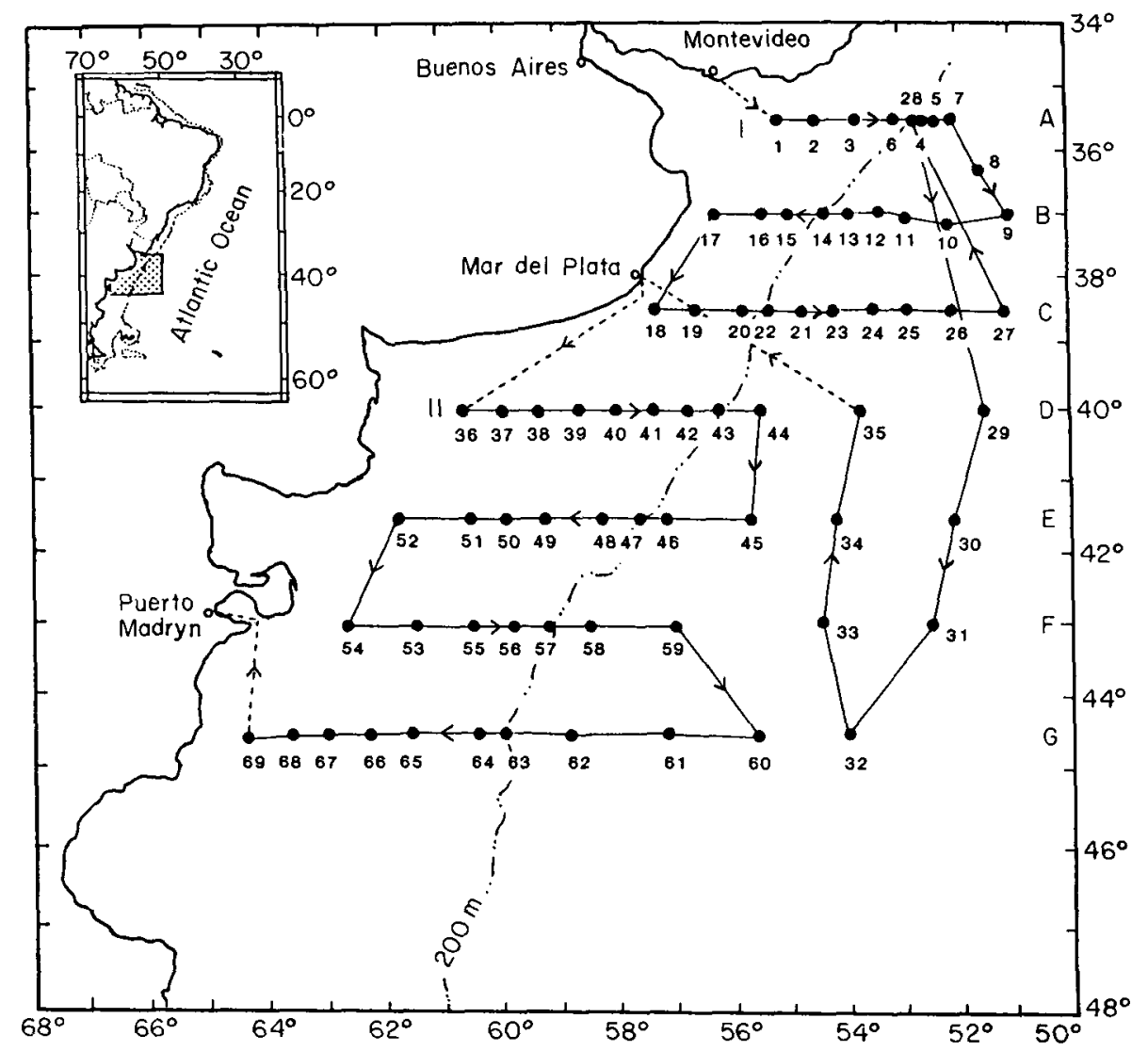

Figure 1. General stations, transects (A-G), and track of "Kaiyo Maru" survey (August-September, 1989).

second of four (D, E, F, G), with a total of 69 stations (Fig. 1).

A total of 59 bongo net stations were established (Fig. 7), each consisting of a standard oblique tow $(200-0 \mathrm{~m})$ made during the night. A bongo net $(0.335-\mathrm{mm}$ mesh) with flowmeter and distance-depth recorder was used.

More intensive samples were taken at station 28. Using the bongo net double messenger system, four sets of oblique tows at five depth layers $(25-0,50-25,75-50$, $100-75,200-100 \mathrm{~m}$ ) were carried out within $24 \mathrm{~h}$. Two additional tows were carried out in the depth zones where most of the larvae were caught $(15-0,30-15 \mathrm{~m})$. Each tow lasted for $15 \mathrm{~min}$, after which the catch was analysed on board to sort cephalopod and fish larvae. The catch from the left net was kept by the Japanese scientists and the one from the right net was shared between the Argentinian and Uruguayan scientists. The samples were preserved in $5 \%$ buffered formalin. Some Rhynchoteuthion larvae were preserved in $70 \%$ alcohol for aging studies from statoliths.

After landing, the cephalopod larvae were identified and measured. Rhynchoteuthion larvae of Illex argentinus were identified in accordance with Leta (1987) and Brunetti $(1988,1990)$. The main criteria were the size of the proboscis suckers and the chromatophore distribution pattern. Suckers were measured to the nearest $0.001 \mathrm{~mm}$; dorsal mantle length (ML), head width (HW), proboscis length (PL) and arm length (AL) were measured to the nearest $0.1 \mathrm{~mm}$.

In order to confirm that the larvae caught by the "Kaiyo Maru" were Illex argentinus, some morphometric relationships were compared with those of the "Shinkai Maru" cruises, where Brunetti (1990) described them. Different body measures ( $\mathrm{HW}, \mathrm{PL}, \mathrm{AL})$ were plotted against ML.

In addition to those samples, 54 oblique night tows from $1000 \mathrm{~m}$ to the surface were made (Fig. 9) using a midwater trawl with a $75 \mathrm{~mm}$ meshed codend and $10 \mathrm{~mm}$ meshed liner. Each catch was sorted into species, when possible, and the weight of each group recorded. All the juveniles of Illex argentinus were measured (dorsal ML to the nearest $0.5 \mathrm{~cm}$ ).

Oceanographic observations were made at 69 stations using a Neill Brown CTD, bathythermograph (XBT) and Nansen casting at several depths down to $1000 \mathrm{~m}$. 

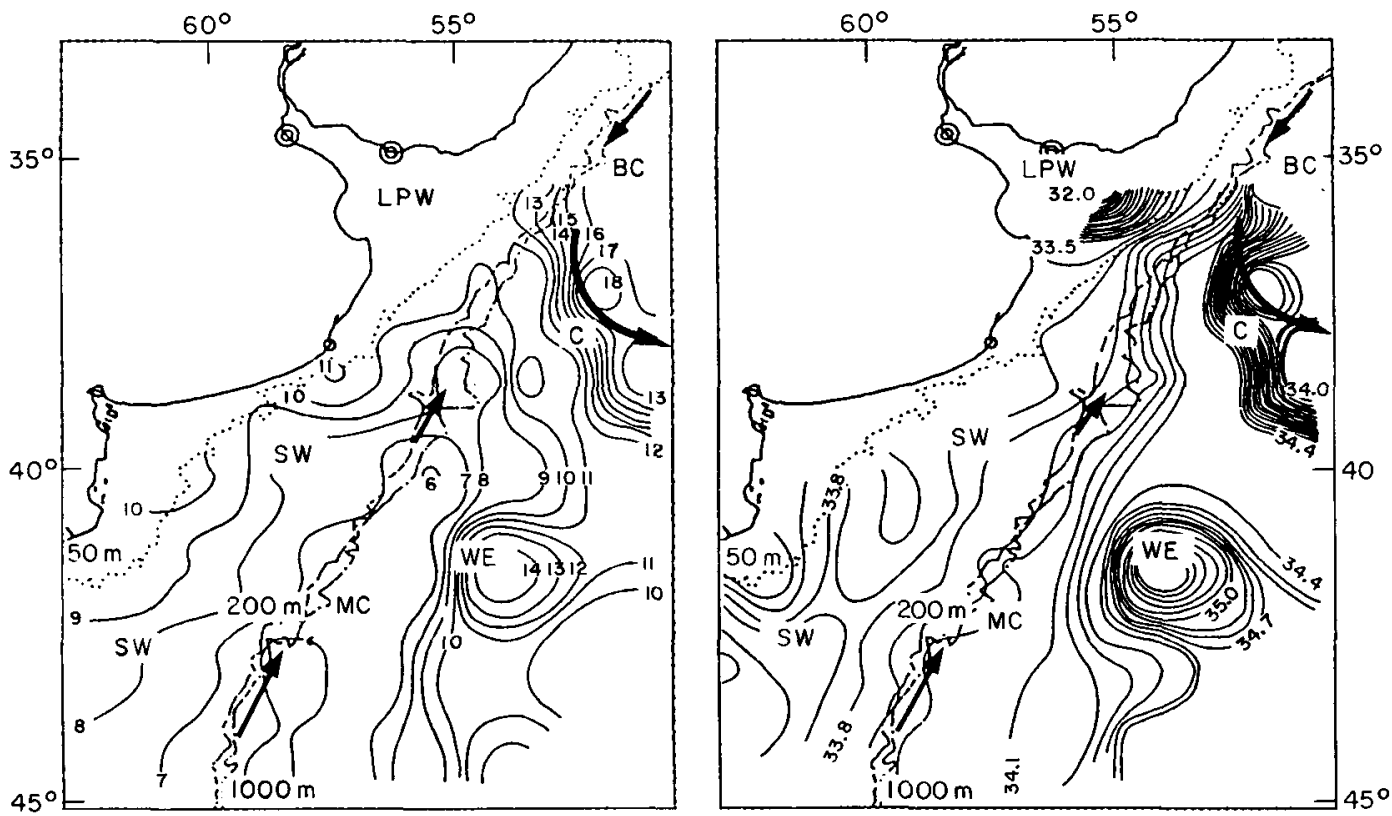

Figure 2. Isotherms and isohalines at $10 \mathrm{~m}$ depth, showing the approximate position of Brazil Current (BC), Malvinas Current (MC), Brazil-Malvinas Confluence (C), shelf waters (SW), La Plata river waters (LPW) and a warm core eddy (WE).

\section{Results}

Oceanographic conditions in the surveyed area

The Brazil Current flows poleward along the continental margin of South America, as part of the western boundary current of the South Atlantic Subtropical Gyre. South of $36^{\circ} \mathrm{S}$, after its confluence with the Malvinas Current, the western boundary of the current, as measured by the sea surface temperature, separates from the shelf edge and turns south-east towards deeper water (Olsen et al., 1988). The meridional displacements of the warm water are accompanied by the intermittent formation of meanders and warm eddies (Legekis and Gordon, 1982) within longitudes $50^{\circ}-55^{\circ} \mathrm{W}$ and latitudes $38^{\circ}-46^{\circ} \mathrm{S}$.

Figure 2 presents $10 \mathrm{~m}$ depth isotherms and isohalines, as recorded by the "Kaiyo Maru", showing the western boundary of the Brazil Current and its confluence with the Malvinas Current $\left(37^{\circ}-39^{\circ} \mathrm{S}\right)$, as well as some meanders and eddies. Figure 3 shows temperature and salinity profiles corresponding to transects $\mathrm{A}$ and $\mathrm{B}$, where the Brazil Current separates from the continental edge.

Lower salinity waters spread on the surface over the subtropical waters of the Brazil Current at stations 5 and 28, transect A (Figs 3 and 8).

The Malvinas Current, which is characterized by salinities between 33.90 and 34.20 , flows north-eastward over the continental slope off Argentina. It originates as a branch of the Antarctic Circumpolar Current. Its western edge, as indicated by surface isotherms, is approximately positioned over the $200 \mathrm{~m}$ isobath and is bounded by continental shelf waters. The northern edge $\left(37^{\circ}-39^{\circ} \mathrm{S}\right)$ is bounded by warm waters, which are associated with the Brazil Current. The eastern boundary of the cold water lies next to meanders and warm core eddies that are also associated with the Brazil Current. The Malvinas Current, after the Brazil-Malvinas confluence, changes its direction and shows south-eastern deviations (Legekis and Gordon, 1982).

A branch of the Antarctic Circumpolar Current, after passing Hornos Cape, flows northward between the Malvinas Islands and Tierra del Fuego Island. This is known as the Occidental Malvinas branch (Balech, 1971, 1986; Fedulov et al., 1990; Brandhorst and Castello, 1971). There waters, which have lower salinities than those of the Malvinas Current, flows towards the northeast over the shelf up to nearly $38^{\circ} \mathrm{S}$, between the $100 \mathrm{~m}$ and $200 \mathrm{~m}$ isobaths, being part of shelf waters.

In the surveyed area, the subantarctic waters of the intermediate shelf (50-100 $\mathrm{m}$ depth) displayed temperatures and salinities which are normal during the winter season. Water temperature and salinity varied minimally both horizontally and vertically $\left(6-10^{\circ} \mathrm{C} ; 33.6-33.8\right.$; Brandhorst and Castello, 1971; Lusquiños and Valdéz, 1971; INIDEP/JAMARC, 1980).

\section{Larval distribution and sizes}

The 35 Rhynchoteuthion larvae caught by the right bongo net during the cruise were identified as Type C (Sato and 

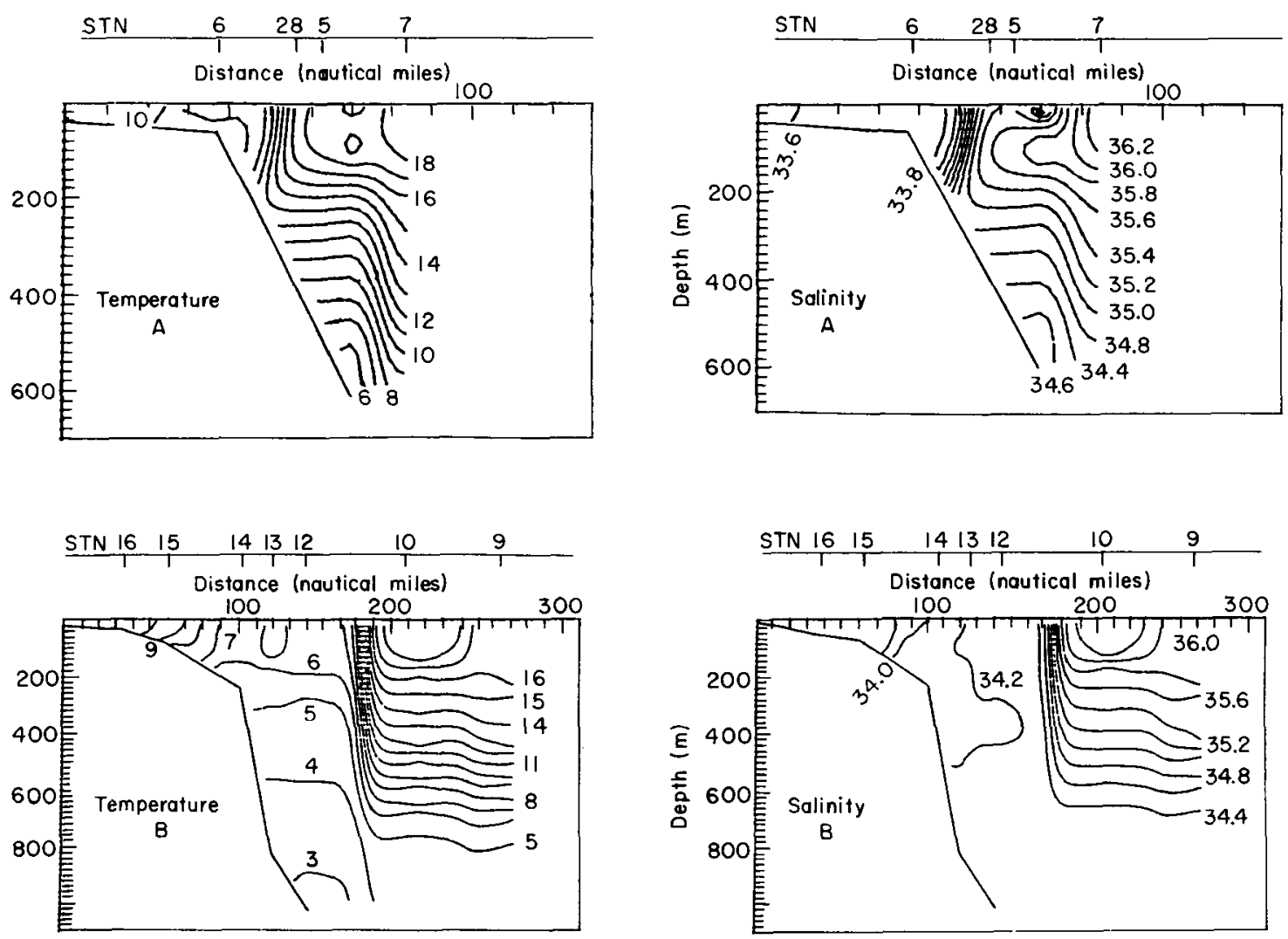

Figure 3. Temperature and salinity profiles corresponding to transects $A$ and $B$.
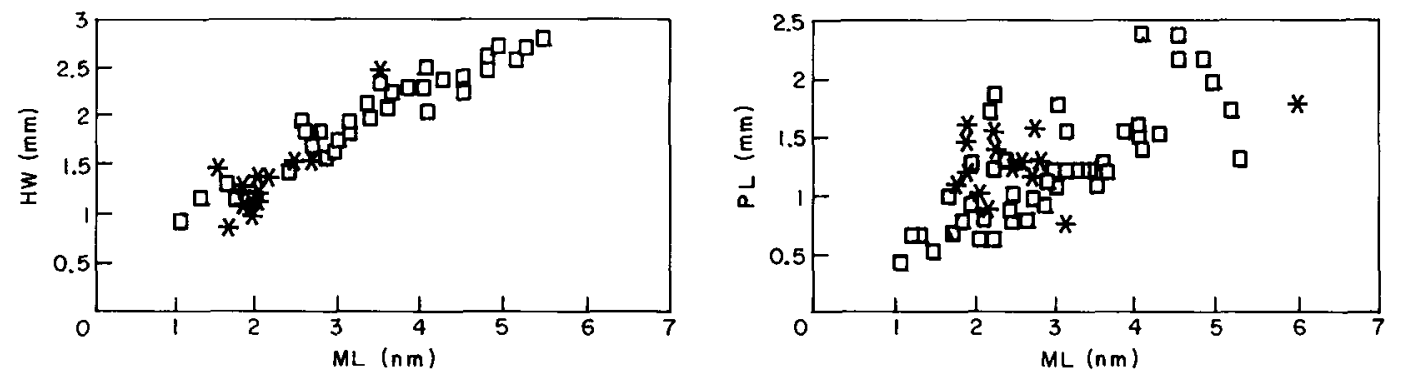

Figure 4. Head width (HW) and proboscis length (PL)-size (ML) scatterplot. *, Kaiyo Maru; $\square$, Shinkai: Maru.

Sawada, 1974) and the species as Illexargentinus. They had eight equal-diameter suckers $(0.038-0.050 \mathrm{~mm})$ on the proboscis tip. The chromatophore pattern on both sides of the head and funnel agreed with that described for Illex argentinus (Brunetti, 1990) from "Shinkai Maru" cruises (INIDEP/JAMARC, 1980). Both the area of larval distribution and their morphology were also in agreement with those suggested for this species during the winter season (Leta, 1987).

The comparison of the larval morphometric relationships with those of the "Shinkai Maru" cruises (Figs 4 and 5) shows that the "Kaiyo Maru" values lie within the
"Shinkai Maru" distributions, so confirming the identity of "Kaiyo Maru" larvae.

Overall, larval mantie length ranged from 1.9 to $6.0 \mathrm{~mm}$, with a mode at $2 \mathrm{~mm}$ (Fig. 6). In those larvae smaller than $2.5 \mathrm{~mm} \mathrm{ML}$, arms I and II were about equally developed. Arms III were small and bore 2-3 suckers, whereas arms IV were represented by minute buds. From $3 \mathrm{~mm}$ ML on, all arms were well developed, with the arm formula being II $>$ I $>$ III $>$ IV.

Among the small specimens, the proboscis was nearly twice as long as arms II. By $3 \mathrm{~mm} \mathrm{ML}$ it was about one and a half times the length of arms II. In the largest of the 

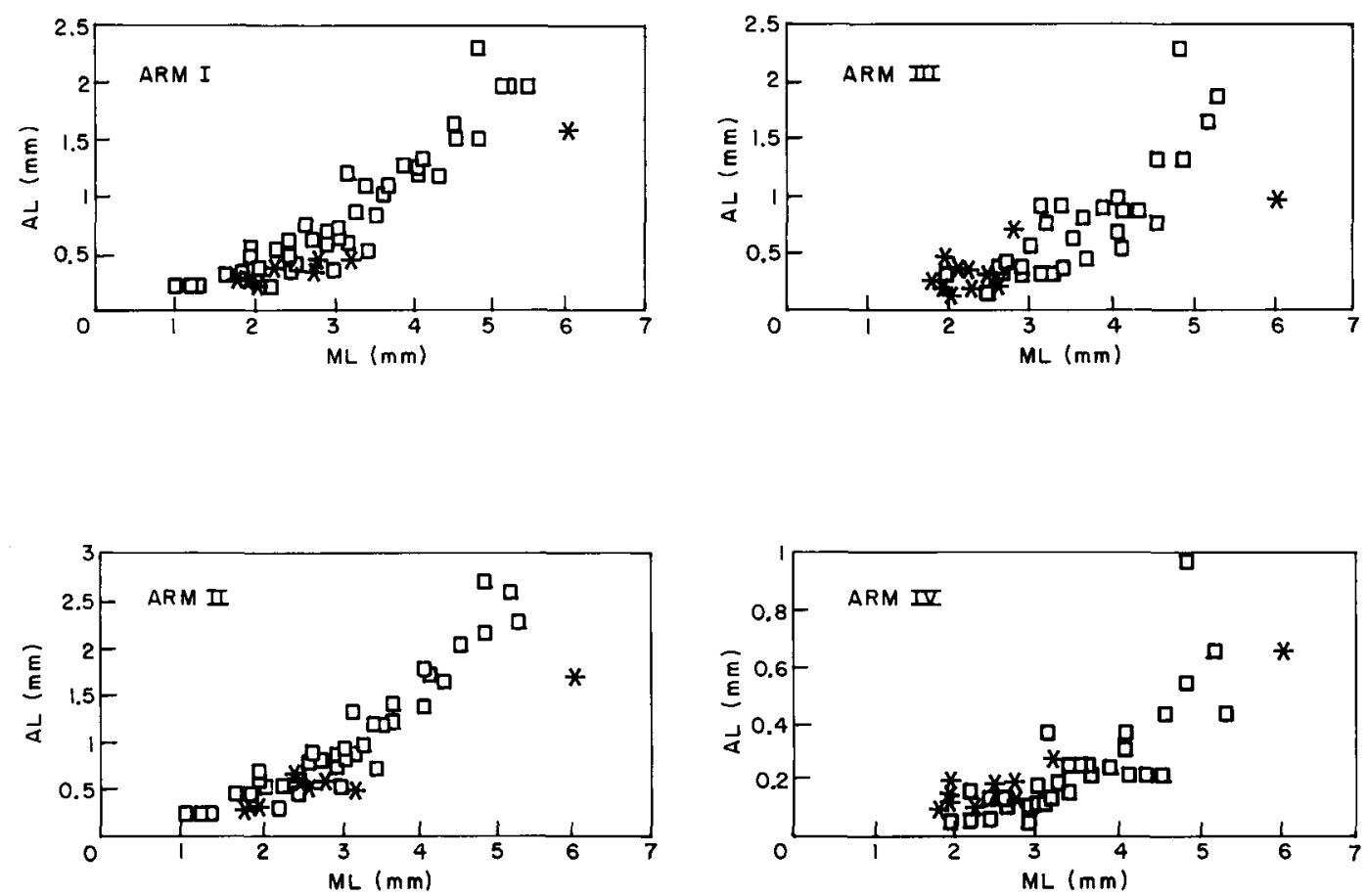

Figure 5. Arms length (AL)-size (ML) scatterplot. *, Kaiyo Maru: $\square$, Shinkai Maru.

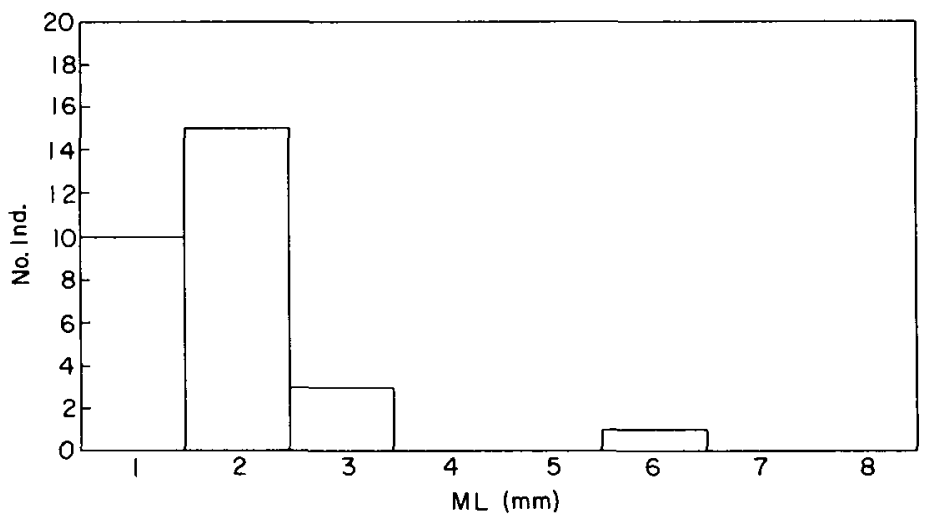

Figure 6. Mantle length distribution of Rhynchoteuthion larvae. $\overline{\mathrm{X}}=2.4 ; \mathrm{S}=1.0 ; \mathrm{N}=29$.

available individuals $(6.0 \mathrm{~mm} \mathrm{ML})$, both the proboscis, which had already begun to divide, and arms II had almost the same length.

All the larvae were caught in five stations from the western boundary of the Brazil Current (Fig. 7). The higher abundances (more than 20 larvae $10 \mathrm{~m}^{-2}$ ) and the smallest sizes (up to $2 \mathrm{~mm} \mathrm{ML}$ ) occurred at stations 10 and 27 , within warm waters $\left(18.9^{\circ} \mathrm{C} ; 36.3\right)$ where the Brazil Current had separated from the shelf edge, turning south-east towards deeper waters. Bigger sizes $(2-3 \mathrm{~mm}$ $\mathrm{ML})$ and lesser abundances (10 larvae $10 \mathrm{~m}^{-2}$ ) were recorded at stations 28,5 , and 7 (transect $A$ ) which were located on the frontal zone between the Brazil Current and shelf waters $\left(14-18^{\circ} \mathrm{C} ; 34.2-36.3\right)$. Only one larva of $6 \mathrm{~mm}$ ML was caught at station 5 .

No larvae were caught in the Malvinas Current or on the shelf where the surface temperature was below $14^{\circ} \mathrm{C}$.

At station 28 , where a depth-stratified sampling was carried out, only 3 of 22 tows resulted in significant catches; one catch each from the $25-0 \mathrm{~m}$ and $30-15 \mathrm{~m}$ layers during the day, and one from the stratum $25-0 \mathrm{~m}$ at night (Fig. 8). There were no larvae in the upper layer $(15-0 \mathrm{~m})$ because of the low salinity waters, which appeared limited to this area. It is therefore suggested that Illex argentinus larvae usually inhabit the 30-15 m layer, above the thermocline, during both day and night. 


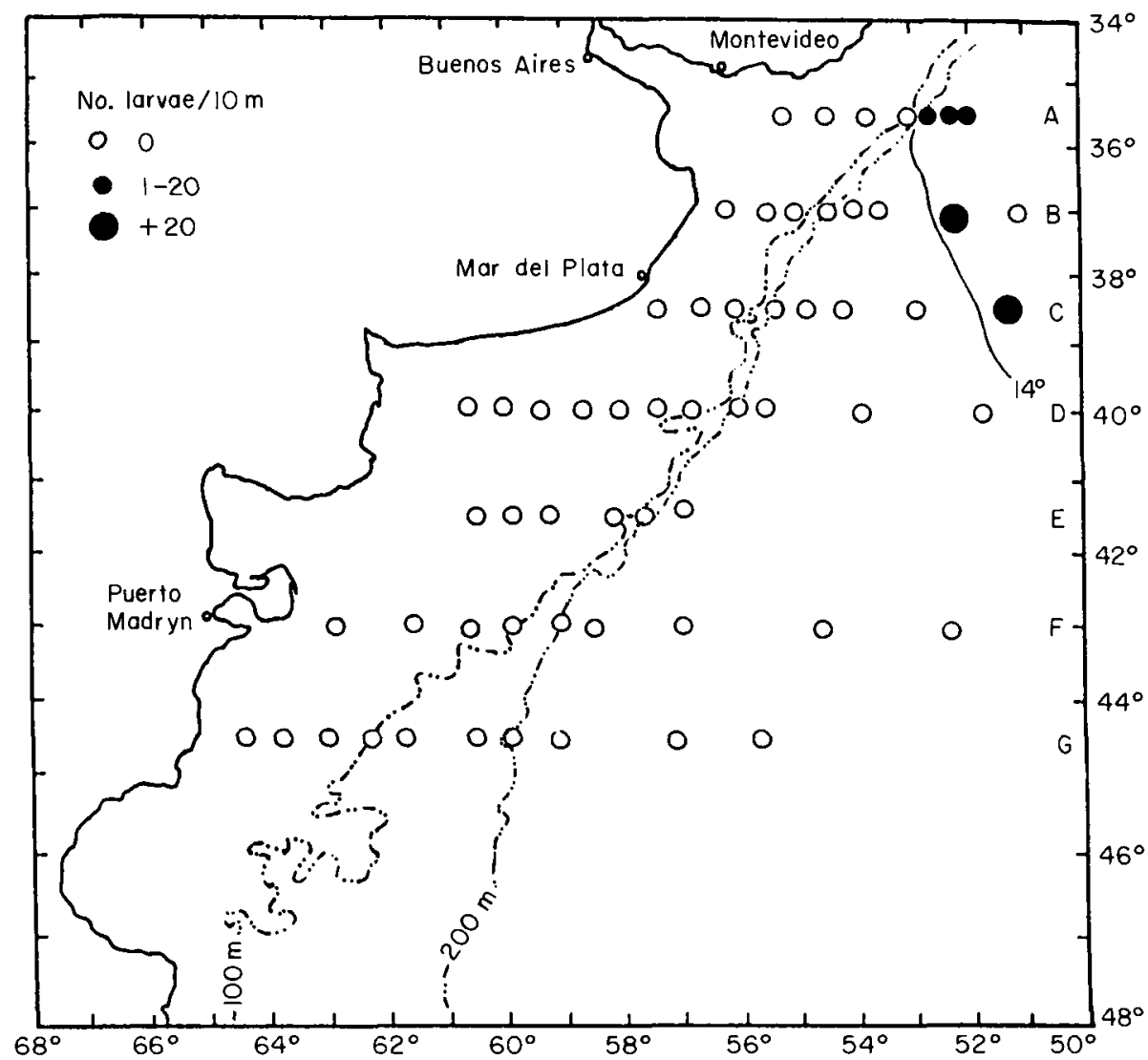

Figure 7. Bongo stations and abundances of Illex argentinus larvae. The $14^{\circ} \mathrm{C}$ isotherm indicates the approximate position of the Brazil Current western edge.
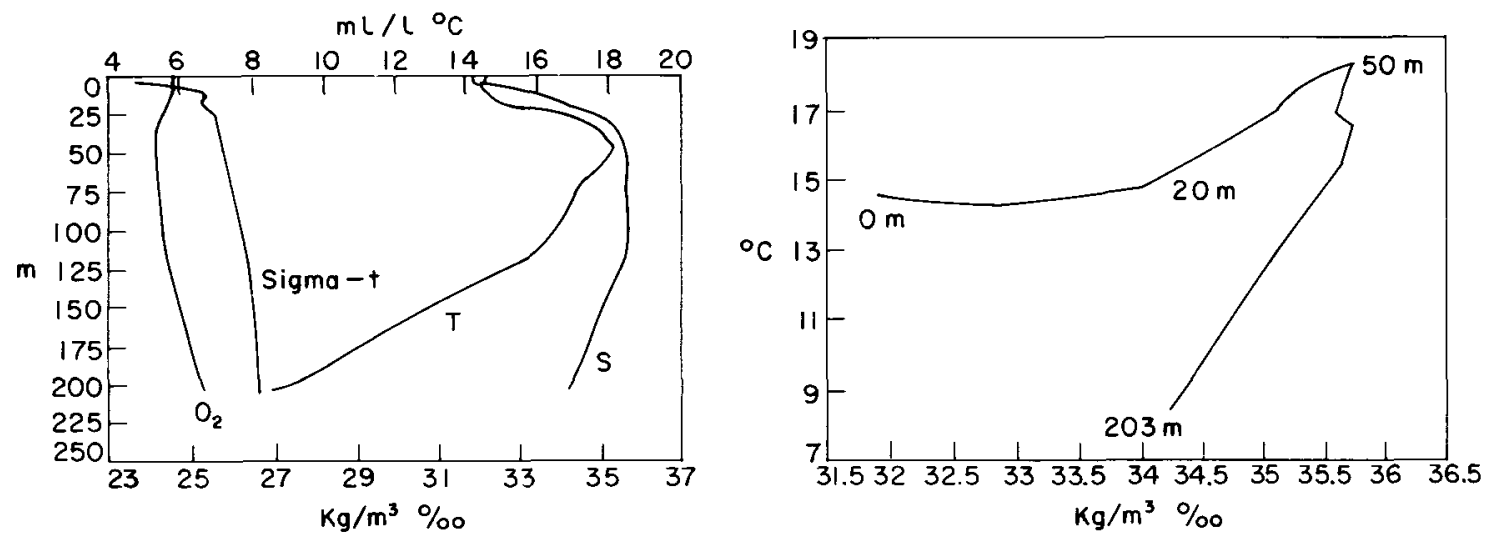

Figure 8. Vertical distributions of temperature $\left({ }^{\circ} \mathrm{C}\right)$ salinity $(\%)$, oxygen $(\mathrm{ml} / \mathrm{l})$ and Sigma-T $(\mathrm{Kg} / \mathrm{m} 3)$ and T-S diagram. Station 28.

Distribution and size of juveniles

A total of 2199 juveniles were caught on the continental shelf and slope waters between $35^{\circ} 30^{\prime} \mathrm{S}$ and $44^{\circ} 30^{\prime} \mathrm{S}$. There were no catches from the open sea (Fig. 9). Only 92 adults were caught in slope waters.
Juveniles ranged from 1 to $11 \mathrm{~cm}$ ML. Mean sizes by transect were estimated between $3.2 \mathrm{~cm}$ and $4.3 \mathrm{~cm} \mathrm{ML}$, the only exception being in Transect B where the mean size was $6.3 \mathrm{~cm} \mathrm{ML}$, so there was no trend of size change with latitude (Fig. 10). No size trends with depth were observed in any transect. 


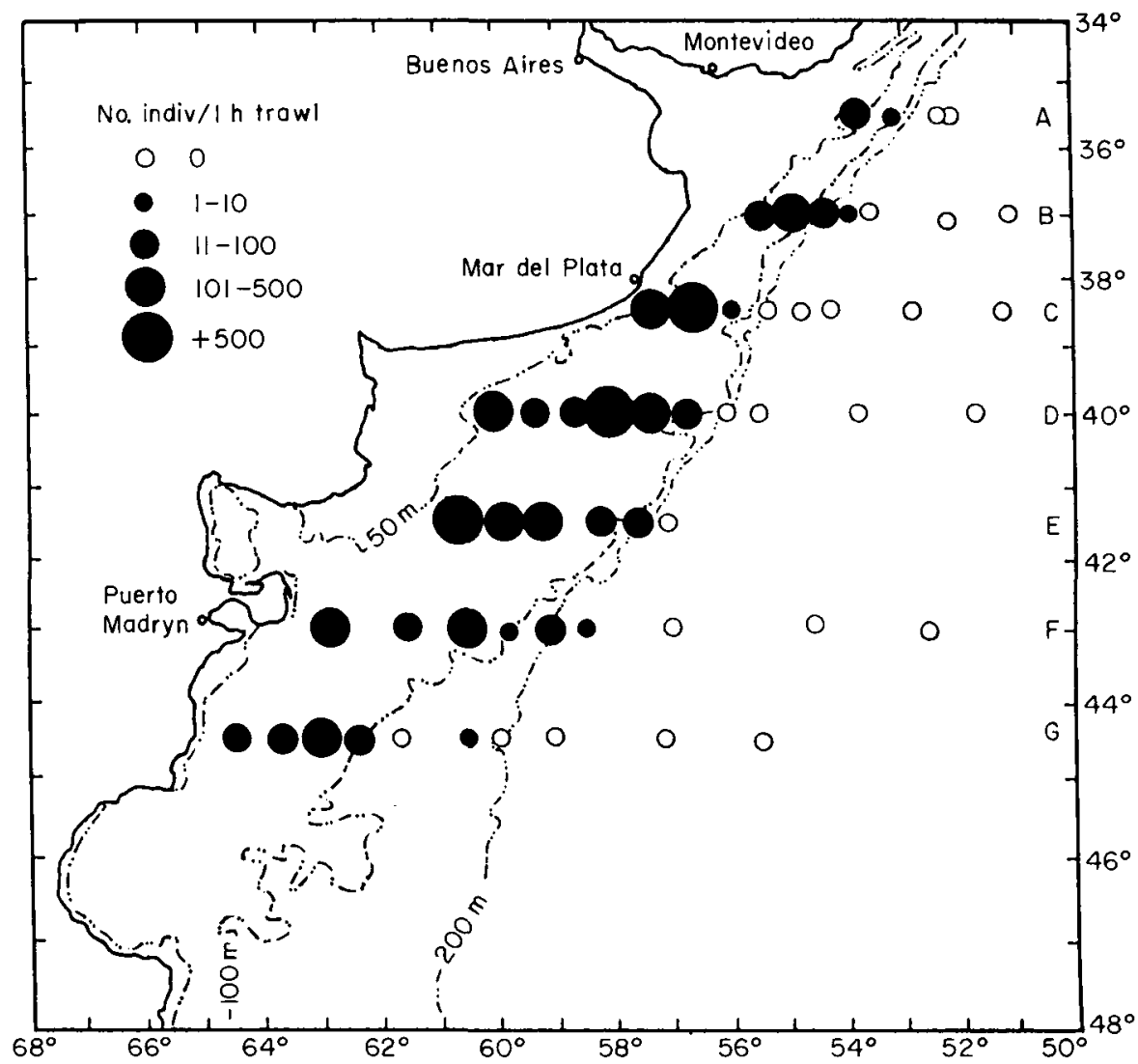

Figure 9. Midwater trawl stations and abundances of juveniles of Illex argentinus. Catches from hauls of varying length are adjusted to give numbers $h^{-1}$.

The highest abundances $\left(+500\right.$ ind $\left.\mathrm{h}^{-1}\right)$ were recorded on the shelf, in transects $\mathrm{C}, \mathrm{D}$ and $\mathrm{E}$, between the 50 and $100 \mathrm{~m}$ isobaths. Decreasing abundances were found towards both southern and northern latitudes.

This distribution pattern and size structure of Illex argentinus has already been observed during the spring on several occasions (Brunetti, 1981, 1988; Hatanaka, 1988), when the juveniles are migrating southwards from their hatchery grounds. Examination of the stomach contents showed that they had been feeding on zooplankton.

\section{Discussion}

Hatanaka et al. (1985) postulated that winter spawning of Illex argentinus was associated with the Brazil Current, so the highest larval abundances should have been found somewhere in warm water.

However, the results of the survey showed few Rhynchoteuthion larvae in Brazilian waters, but high abundances of juveniles in cold shelf waters. The date of hatching of these juveniles can be estimated as two or three months before the cruise.
The exact position of the early winter-spawning ground, which is believed to be off the shelf, still remains unknown because no mating or spent individuals were found.

According to our data, it is possible that spawning takes place along the Malvinas Current from north of the Malvinas Islands. The egg masses might then be transported by the Current towards the north, up to $37-39^{\circ} \mathrm{S}$, where they would enter the subtropical waters of the Brazil Current. Once there, embryonic development would be accelerated. It is worth noting here that the embryonic development of a closely related species, Illex illecebrosus, occurs only at temperatures above $13^{\circ} \mathrm{C}$ (O'Dor et al., 1982). Since Illex argentinus larvae were never found below $14^{\circ} \mathrm{C}$, it is possible that similar constraints on embryonic development affect the spawning and larval distribution of this species. The Brazil Current, in turn, would play the main role in carrying the larvae from the northern part of the outer shelf $\left(34^{\circ}-36^{\circ} \mathrm{S}\right)$ to the intermediate shelf.

Larvae from early winter-spawning were also found by Leta (1987) and Haimovici et al.(MS) in subtropical waters between $29^{\circ}$ and $36^{\circ} \mathrm{S}$. In the northern part $\left(29^{\circ}-32^{\circ} \mathrm{S}\right)$ they 

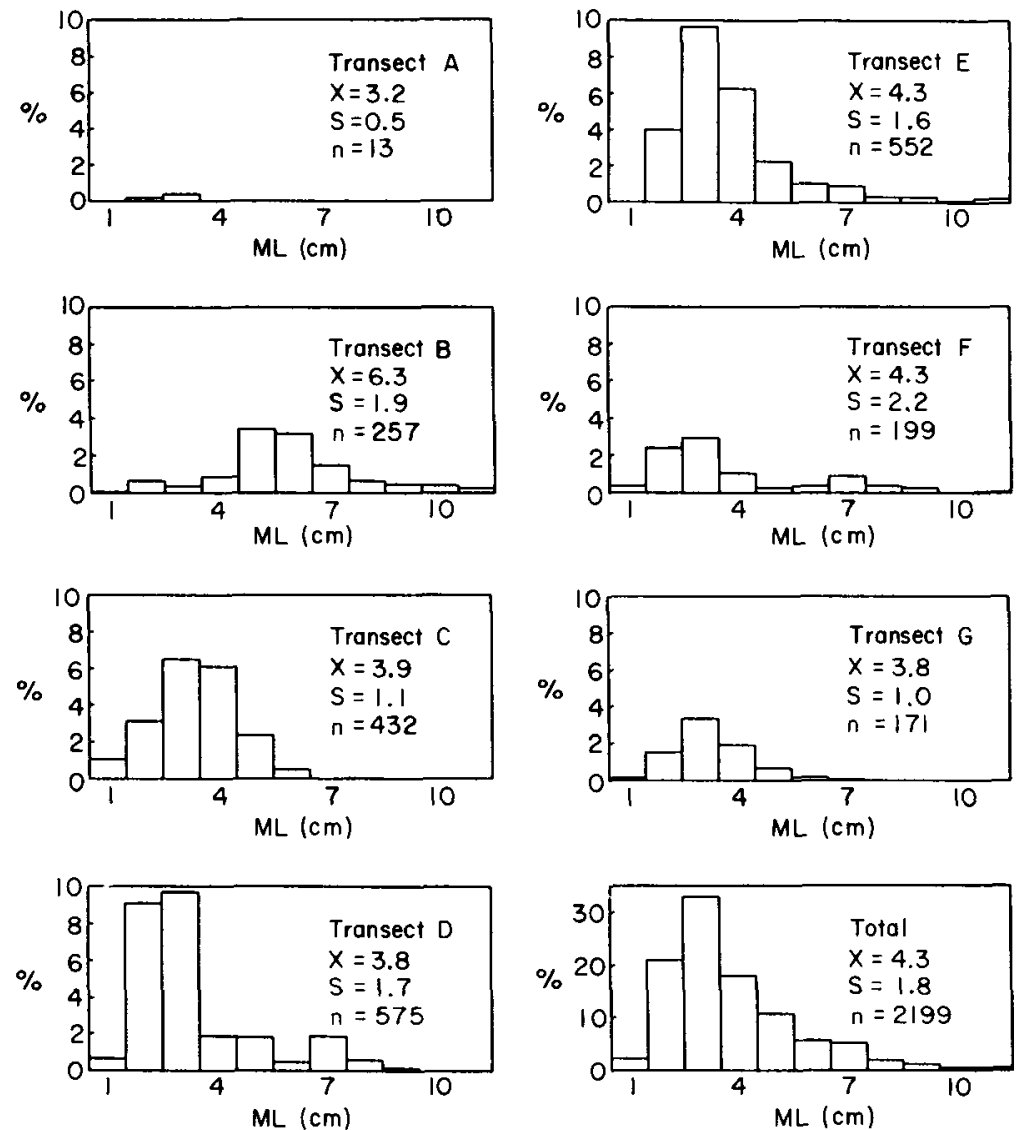

Figure 10. Mantle length frequency distribution by transect and total.

occurred in warm shelf waters. From $32^{\circ}$ to $36^{\circ} \mathrm{S}$ they were collected from the outer shelf and slope waters of the Brazil Current, adjacent to the front with shelf subantarctic waters.

Fewer of these larvae are carried towards the oceanic region by the Brazil Current, after the Malvinas-Brazil confluence. This results in a cohort of juveniles inhabiting oceanic areas. They were found during the cruise of the Soviet RV "Evrika" (Anon., 1989; Brunetti and Rossi, 1990).

In addition to this spawning group, two others have been found for Illex argentinus in the summer and spring. Larvae from summer-spawning groups (Brunetti, 1990) inhabit the shelf between $43^{\circ}$ and $47^{\circ} \mathrm{S}$. They are associated with a tidal front which is formed by well-mixed coastal waters and shelf stratified waters (Carreto et al., 1986; Glorioso, 1987). These larvae were collected at temperatures above $14^{\circ} \mathrm{C}$ during January-March. In the same area and season, spawning and spent adults are caught (Brunetti, 1981, 1990; Brunetti and Perez Comas, 1989). Clearly, both spawning and hatchery grounds overlap.

Larvae from spring-spawning groups (Leta, 1987; Brunetti, 1990; Haimovici et al., MS) were found between $32^{\circ}$ and $39^{\circ} \mathrm{S}$ in warm shelf waters during OctoberNovember. Spawning and spent adults were caught with larvae between $38^{\circ}$ and $40^{\circ} \mathrm{S}$ (Brunetti, 1981).

In any spawning group, larvae are always caught at temperatures above $14^{\circ} \mathrm{C}$ either from tropical and subtropical waters or from the upper warm layers of subantarctic shelf waters.

The distribution of juveniles agrees with the zooplankton concentrations, and the distribution of zooplankton off Argentina shows a sharp seasonality. There is a clear increase in the zooplankton biomass from winter to summer, the lower density values being found in winter in the whole area. From then on, a shift in high zooplankton production area takes place, beginning in the coastal regions and moving towards the slope, where the influence of the Malvinas Current is evident. High densities, up to $1300 \mathrm{~mm}^{3} \mathrm{~m}^{-3}$, can first be observed on the shelf between $37^{\circ}$ and $43^{\circ} \mathrm{S}$ during the spring, but only during the summer in the more southern area, below $45^{\circ} \mathrm{S}$, where densities up to $1014 \mathrm{~mm}^{3} \mathrm{~m}^{-3}$ are found. So, there is a time displacement of the phytoplankton and zooplankton spring blooms in two directions, west to east and north to south (Carreto et al. 1981a,b; Ciechomski and Sánchez, 1983). 


\section{Acknowledgements}

The authors thank the Japanese Fisheries Agency for their invitation to participate in the cruise. They are specially grateful to Captain T. Morooka, the Officers, crew and scientists of the "Kaiyo Maru" for their hospitality and cooperation during the cruise.

\section{References}

Anon. 1989. Informe sobre la primera expedición soviéticoargentina en el Atlántico Sudoccidental a bordo del B/I "EVRIKA" (agosto-octubre 1988). AtlantNIRO, Kaliningrado. $215 \mathrm{pp}$.

Balech, E. 1971. Notas históricas y críticas de la oceanografia biológica argentina. Serv. Hidrogr. Nav., Buenos Aires, H-1027: 1-57.

Balech, E. 1986. De nuevo sobre la oceanografia frente a la Argentina. Serv. Hidrogr. Nav., Buenos Aires, H-645: 1-21.

Brandhorst, W., and Castello, J. P. 1971. Evaluación de los recursos de anchoita (Engraulis anchoita) frente a la Argentina y Uruguay. I. Las condiciones oceanográficas, sinopsis del conocimiento actual sobre la anchoita y el plan para su evaluación Proy. Des. Pesq., Mar del Plata, Ser. Infs. Téc., 29: 1-63.

Brunetti, N. E. 1981. Distribución de tallas y biología reproductiva del calamar (Illex argentinus) en el Mar Argentino (Campañas del B/I Shinkai Maru 1978-1979). In Campañas de investigación pesquera realizadas en el Mar Argentino por los B/I Shinkai Maru y Walther Herwig y el B/P Marburg, años 1978 y 1979. Resultados de la parte argentina. Ed. by V. Angelescu. INIDEP. Contrib. 383: 119-127.

Brunetti, N. E. 1988. Contribución al conocimiento biológico pesquero del calamar argentino (Cephalopoda, Ommastrephidae Illex argentinus). Tesis doctoral. Fac. Cs. Nat. Museo, Universidad Nacional de La Plata: 135 pp.

Brunetti, N. E. 1990. Description of Rhynchoteuthion larvae of Illex argentinus from summer spawning subpopulation. J. Plankton Res., 12: 1045-1057.

Brunetti, N. E., and Perez Comas, J. A. 1989. Abundancia, distribución y estructura poblacional del calamar (Illex argentinus) en aguas de la plataforma patagónica en diciembre de 1986 y enero-febrero de 1987. Frente Marítimo. Vol. 5 Sec. A: 61-70.

Brunetti, N. E., and Rossi, G. R. 1990. Informe preliminar sobre la campaña argentino-soviética en el B/I EVRIKA (agostooctubre 1988). INIDEP. Inf. Téc. No 1. 31 pp.

Carreto, J. I., Negri, R., and Benavides, H. 1981a. Fitoplancton pigmentos y nutrientes. Resultados campañas III y VI del B/I "Shinkai Maru" 1978. In Campañas de investigación pesquera realizadas en el Mar Argentino por los B/I Shinkai Maru y Walther Herwig y el B/P Marburg, años 1978 y 1979. Resultados de la parte argentina. Ed. by V. Angelescu. INIDEP. Contrib. 383: 181-201.

Carreto, J. I., Ramirez, F., and Dato, C. 1981b. Zooplancton y producción secundaria. Parte II. Distribución y variación estacional de la biomasa planctónica. In Campañas de investigación pesquera realizadas en el Mar Argentino por los $\mathrm{B} / \mathrm{I}$ Shinkai Maru y Walther Herwig y el B/P Marburg, años 1978 y 1979. Resultados de la parte argentina. Ed. by V. Angelescu. INIDEP. Contrib. 383: 213-232.

Carreto, J. I., Benavides, H. R., Negri, R. M., and Glorioso, P. D 1986. Toxic red-tide in the Argentine Sea. Phytoplankton distribution and survival of the toxic dinoflagellate Gonyaulax excavata in a frontal area. J. Plankton Res., 8: 171-238.

Ciechomski, J. D., and Sánchez, R.P. 1983. Relationship between ichthyoplankton abundance and associated zooplankton biomass in the shelf waters off Argentina. Biol. Oc. 3: 77-101

Fedulov, P. P., Remeslo, A. V., Burykin, S. N., and Polishchuk, J. A. 1990. Variabilidad de la Corriente de Malvinas. Frente Maritimo, 6(A): 121-127.

Glorioso, P. D. 1987. Temperature distribution related to shelfsea fronts on the Patagonian Shelf. Cont. Shelf Res., 7: 27-34.

Haimovici, M., Vidal, E. A. G., and Perez, J. A. A. (MS). Larvae of Illex argentinus (Castellanos, 1960) in five surveys on the continental shelf of Southern Brazil.

Hatanaka, H. 1988. Feeding migration of short-finned squid Illex argentinus in the waters off Argentina. Nippon Suisan Gakkaishi, 54: 1343-1349.

Hatanaka, H., Kawahara, S., Uozumi, J., and Kasahara, S. 1985. Comparation of life cycles of five ommastrephid squids fished by Japan: Todarodes pacificus, Illex illecebrosus, Illex argentinus, Nototodarus sloani sloani and Nototodarus sloani gouldi. NAFO. Sci. Coun. Studies, 9: 59-68.

Instituto Nacional de Investigación y Desarrollo Pesquero/ Japan Marine and Fishery Resources Research Center. 1980 Final report of the exploratory fishing cruises carried out off Argentine by R/V Shinkai Maru from April 1978 to April 1979. (Doc. mim.). Mar del Plata, 107 pp.

Legekis, M. R., and Gordon, A. L. 1982. Satellite observations of the Brazil and Falkland Currents 1975 to 1976 and 1978. Deep-Sea Res., 29(3A): 375-401.

Leta, M. R. 1987. Descripción de los huevos, larvas y juveniles de Illex argentinus (Ommastrephidae) y juveniles de Loligo brasiliensis (Loliginidae) en la Zona Común de Pesca Argentino-Uruguaya. Publ. Cient. INAPE, 1: 1-8.

Lusquiños, A., and Valdéz, A. 1971. Aportes al conocimiento de las masas de agua del Atlántico Sudoccidental. Serv. Hidr. Naval, Buenos Aires. H.659. 42 pp.

O'Dor, R. K., Balch, N., Foy, E. A., Hirtle, R. W. M., Johnston, D. A., and Amaratunga, T. 1982. Embryonic development of the squid, Illex illecebrosus, and the effect of the temperature on development rates. J. Northw. Atl. Fish. Sci., 3:41-45.

Olson, D. B., Podestá, G. P., Evans, R. H., and Brown, O. B. 1988. Temporal variations in the separation of Brazil and Malvinas Currents. Deep-Sea Res., 35: 1971-1990.

Parfeniuk, A. V., Froerman, Y. M., and Golub, A. N. (MS) Rasgos característicos de la distribución de los juveniles del calamar argentino en el área de la cuenca argentina. Presentado en el VI Simposio Científico de la Comisión Técnica Mixta del Frente Marítimo. Montevideo, Diciembre 1989.

Sato, K., and Sawada, T. 1974. Studies on larvae of decapod cephalopods in the water of the Izu Peninsula. I. Bull. Shizuoka Prefectural Exp. Stn., 8: 11-21. 
